\title{
Continuous Real-Time Water Information- An Important Kansas Resource
}

\author{
By Brian Loving, James Putnam, and Donita Turk
}

Continuous real-time information on streams, lakes, and groundwater is an important Kansas resource that can safeguard lives and property, and ensure adequate water resources for a healthy State economy. The U.S. Geological Survey (USGS) operates approximately 230 water-monitoring stations at Kansas streams, lakes, and groundwater sites. Most of these stations are funded cooperatively in partnerships with local, tribal, State, or other Federal agencies. The USGS real-time water-monitoring network provides long-term, accurate, and objective information that meets the needs of many customers. Whether the customer is a water-management or water-quality agency, an emergency planner, a power or navigational official, a farmer, a canoeist, or a fisherman, all can benefit from the continuous real-time water information gathered by the USGS.

\section{Water-Monitoring Network}

The USGS has collected hydrologic data in Kansas for more than 100 years. The first USGS continuous streamflowmonitoring station in Kansas, Cimarron River near Liberal, began recording data on October 1, 1895. With time, the USGS water-monitoring network (fig. 1) has changed as new needs for water information have emerged and new technologies for data collection, analysis, and dissemination have evolved.

The most profound change in the USGS water-monitoring network in Kansas has been the development and widespread use of continuous real-time data. All continuous monitoring stations in Kansas are equipped with automated data-collection platforms (DCPs) that use satellite technology to transmit data 24 hours a day directly to the USGS office in Lawrence, and

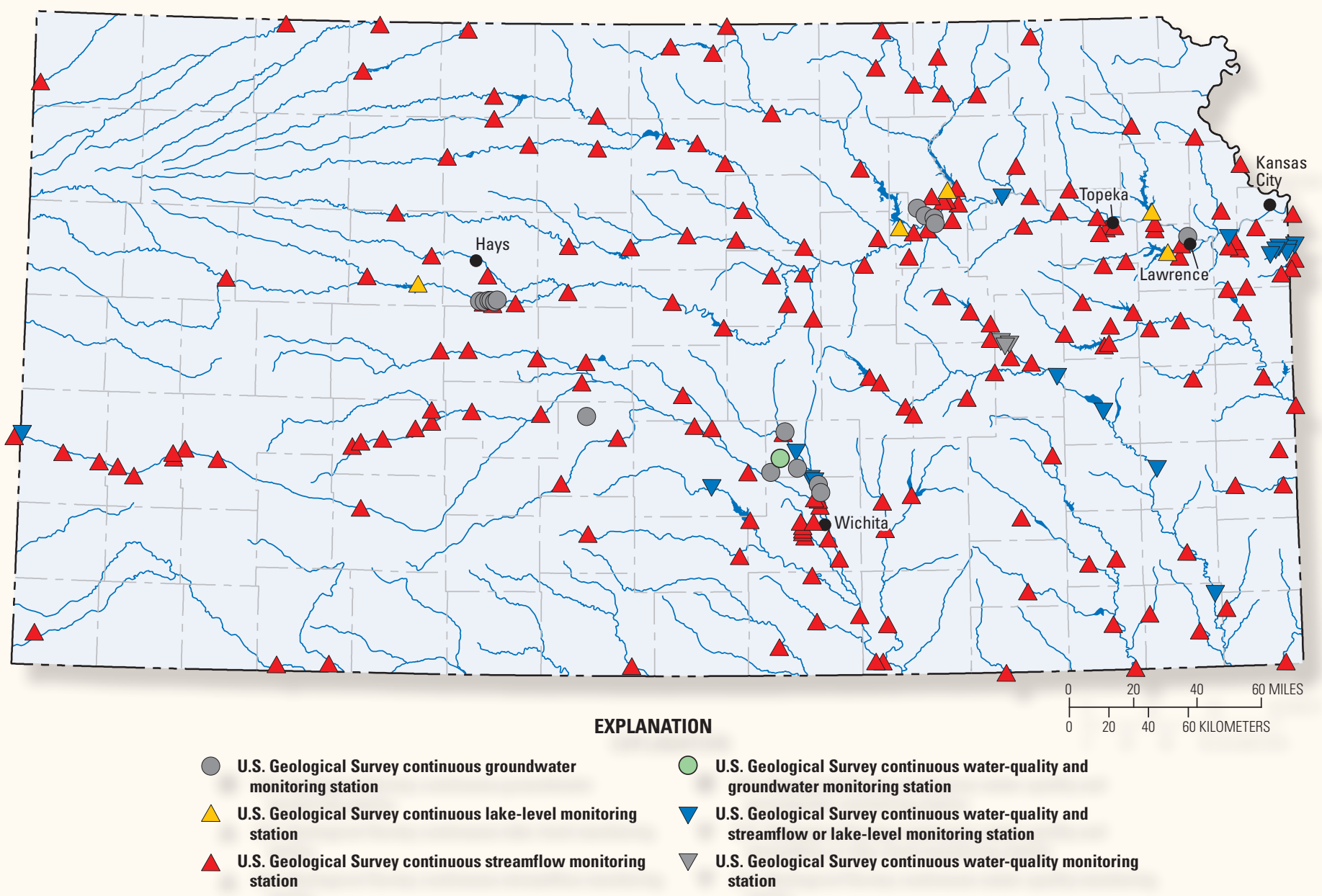

Figure 1. Location of U.S. Geological Survey continuous real-time water-monitoring stations in Kansas as of 2013. 


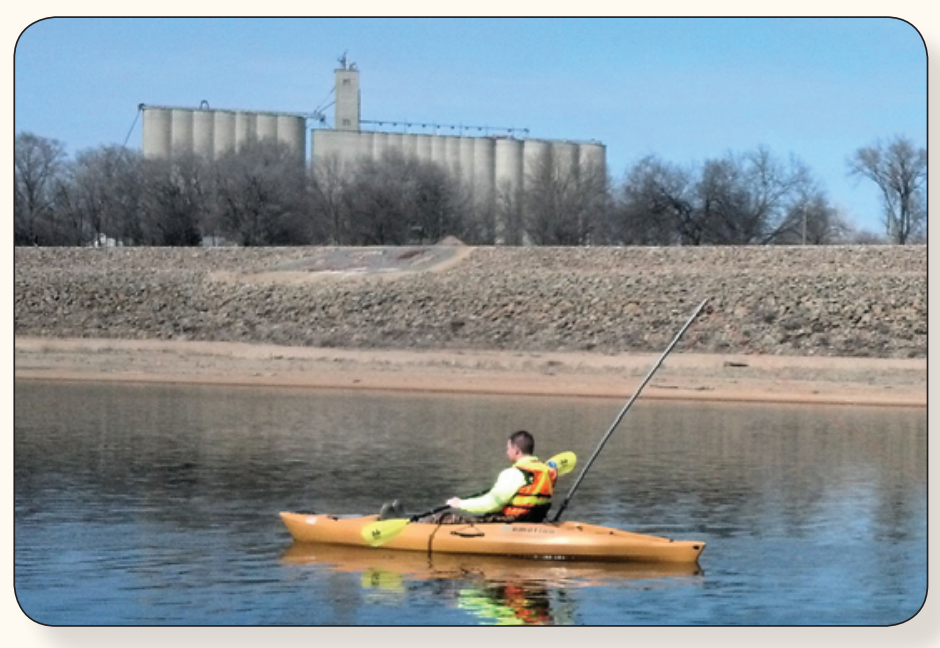

Kayaking on Kansas River below Bowersock Dam in Lawrence, Kansas. Photograph by Arin Peters, U.S. Geological Survey.

then the data are made available on the internet. These real-time stations provide critical information for reservoir operations, river forecasting, flood warnings, water-supply management, environmental monitoring, and recreational use of the State's rivers and lakes.

\section{Real-Time Streamflow and Lake-Level Information}

Continuous real-time streamflow and water-level information is available on the internet for about 200 monitoring stations on streams and 12 locations on lakes in Kansas as of 2013 (fig. 1). Instantaneous discharge (streamflow) and gage-height (water level or stage) data recorded at the monitoring stations are relayed by satellite to USGS computers and processed hourly or more frequently during floods for distribution on the internet. Real-time streamflow and lake-level information is available at $h t t p: / /$ waterdata.usgs.gov/ks/nwis/rt.

WaterWatch (http://waterwatch.usgs.gov/) provides a variety of maps, charts, tables and interactive tools that present the current and historical streamflow data collected by USGS in a meaningful context.

The USGS WaterAlert service (http://water.usgs.gov/ wateralert) sends email or text messages when certain hydrologic measurements from USGS real-time data collection stations exceed user-defined thresholds.

\section{Continuous real-time streamflow and lake-level information from the USGS is used by:}

State and local water-management and supply agencies - to plan, monitor, and adjust water-withdrawal and watertreatment strategies for protecting public health, especially during a drought.

National Weather Service - to determine flood stages for various streams and to help forecast when and where streams will crest during floods.

U.S. Army Corps of Engineers - to aid in the scheduling of reservoir releases to reduce damage from floods, maintain water supplies, allow navigation, and meet water-quality and ecosystems standards.

Kansas Department of Transportation - to safely and efficiently design bridges, highways, and culverts that will convey sufficient streamflow so that roadways and bridges remain above water during flooding and avoid structural damage.

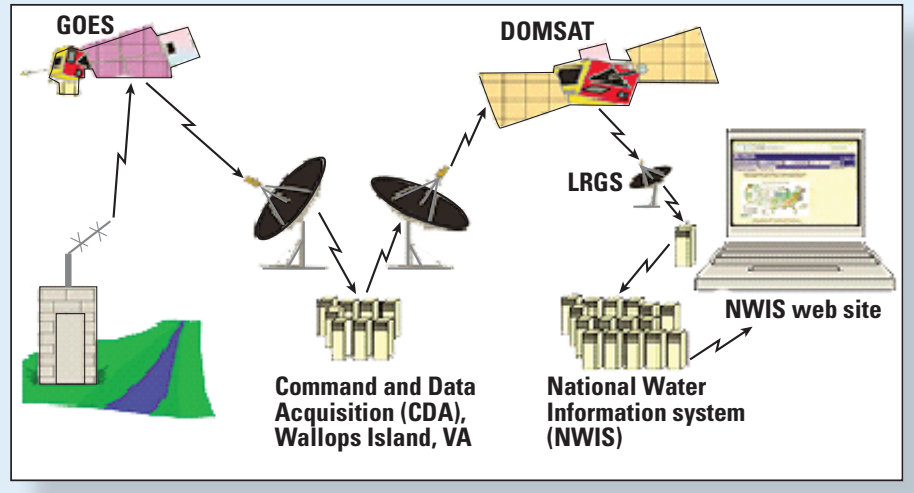

Water data from the river to the internet.

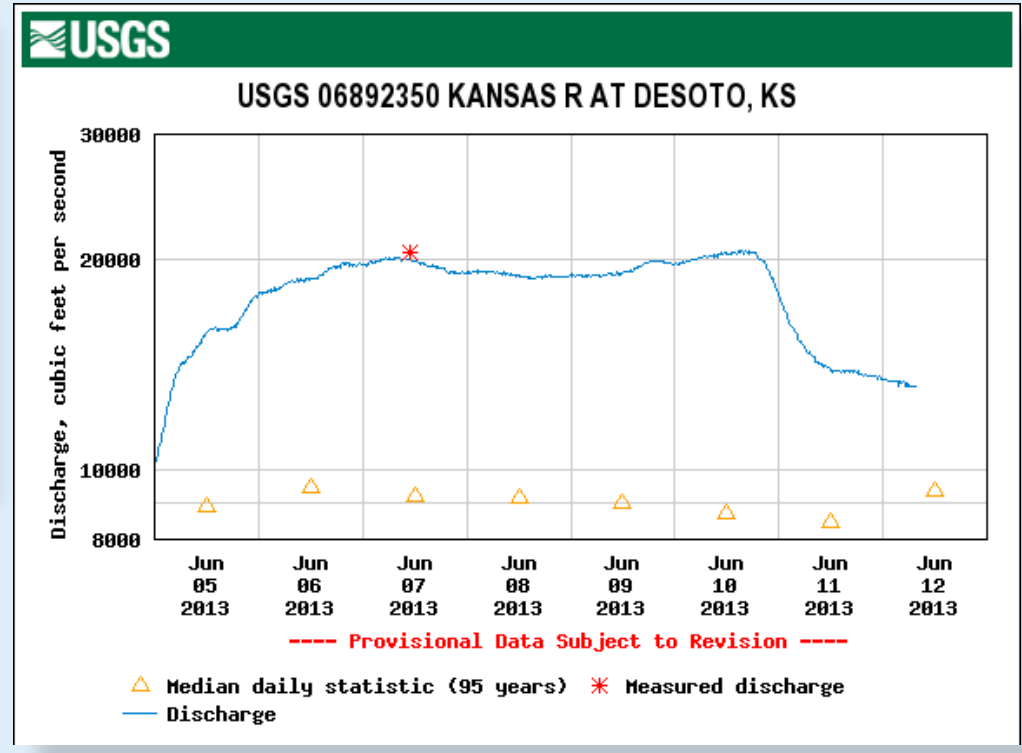

Real-time streamflow data.

http://waterdata.usgs.gov/ks/nwis/rt/

Streamgage on Missouri River at Leavenworth, Kansas. Photograph by Craig Painter, U.S. Geological Survey. 


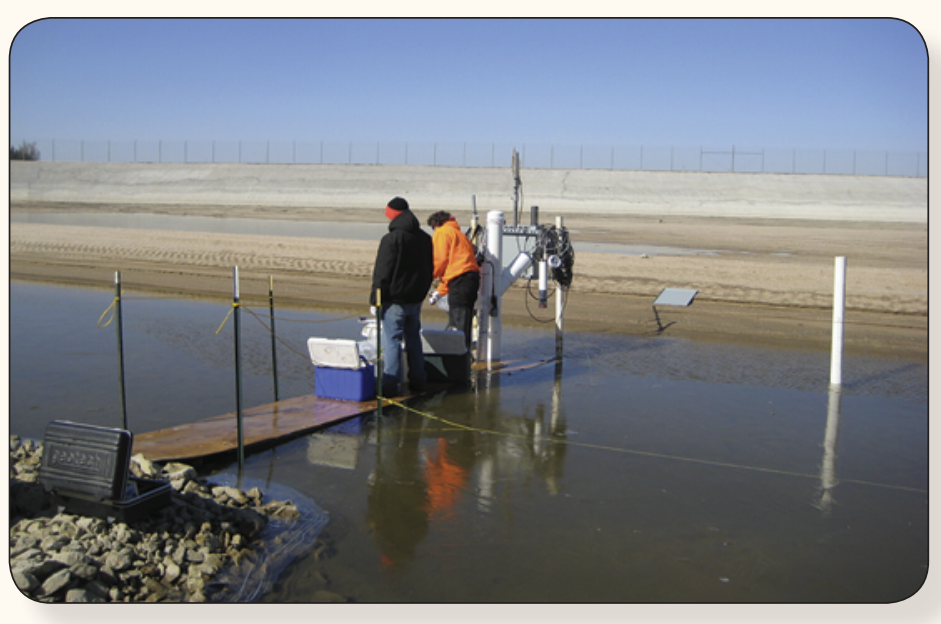

Hydrologists sampling water in recharge basin as part of the Equus Beds aquifer storage and recovery project. Photograph by Linda Garinger, U.S. Geological Survey.

Federal Emergency Management Agency - to delineate flood-prone areas, develop flood-insurance rates, and address emergency-response needs before, during, and after flooding.

Fishermen, swimmers, and boaters - to monitor water conditions for safe, optimal recreational use.

Farmers and Ranchers - to monitor the availability of water in streams for irrigation and livestock.

\section{Real-Time Groundwater Information}

Continuous real-time groundwater information from about 20 monitoring wells in Kansas (fig. 1) is available at http://waterdata.usgs.gov/ks/nwis/gw. Available information on groundwater may include groundwater levels, water temperature, barometric pressure, and specific conductance. This information is recorded at 1-hour intervals and transmitted by satellite to the USGS office in Lawrence, Kansas.

\section{Real-Time Water-Quality Information}

At selected streamgages and lake-monitoring stations, the USGS maintains instruments that continuously record physical and chemical characteristics of the water, including temperature, dissolved oxygen, turbidity, $\mathrm{pH}$, conductance, and nitrate. This real-time information is available on a national basis at http://waterwatch.usgs.gov/wqwatch/.

This water-quality information is recorded at 5-minute to 1-hour intervals, stored in data loggers, and transmitted hourly by satellite to the internet. For some monitoring stations, the continuously recorded data and water samples collected are being used to develop statistical relations to compute estimates of continuous data for constituents that cannot be measured continuously, such as suspended-sediment concentration. Although there are accuracy limitations, these real-time estimates of water quality can have considerable utility for protecting human

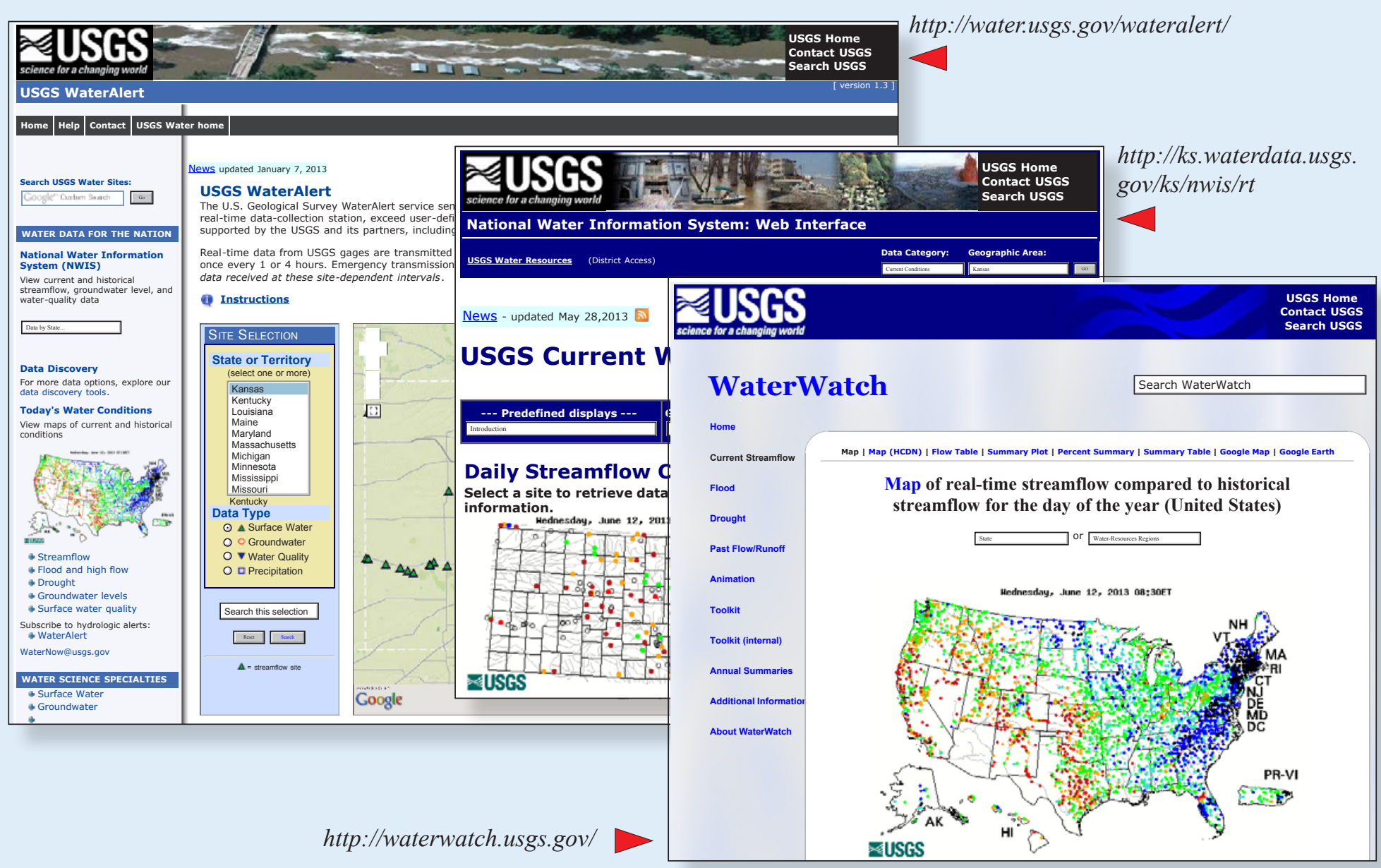


health and ecosystems. Information displayed on the USGS National Real-Time Water Quality Web site includes real-time data graphs and data tables, summary statistics, and statistical model information and documentation. This information can be accessed at http://nrtwq.usgs.gov/.

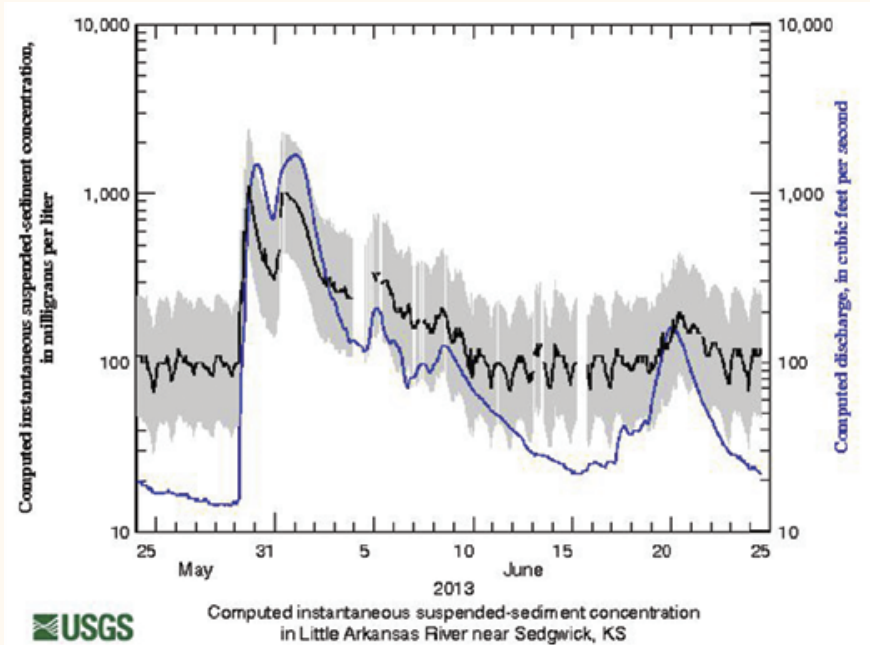

Graph showing continuous computed suspended-sediment concentration and streamflow (gray area indicates 90-percent prediction intervals).

\section{Continuous real-time water-quality information from the USGS is used to:}

- Monitor water quality at surface-water and groundwater sites near Wichita to provide information in support of the Aquifer Storage and Recovery project at the Equus Beds, a major water resource for Wichita;

- Provide taste-and-odor and algal toxin warning to water utilities so water treatment can be altered appropriately;

- Immediately identify undesirable levels of water-quality constituents in streams, lakes and aquifers;

- Determine the effects of wastewater discharge and treatment facility upgrades on biological conditions in streams;

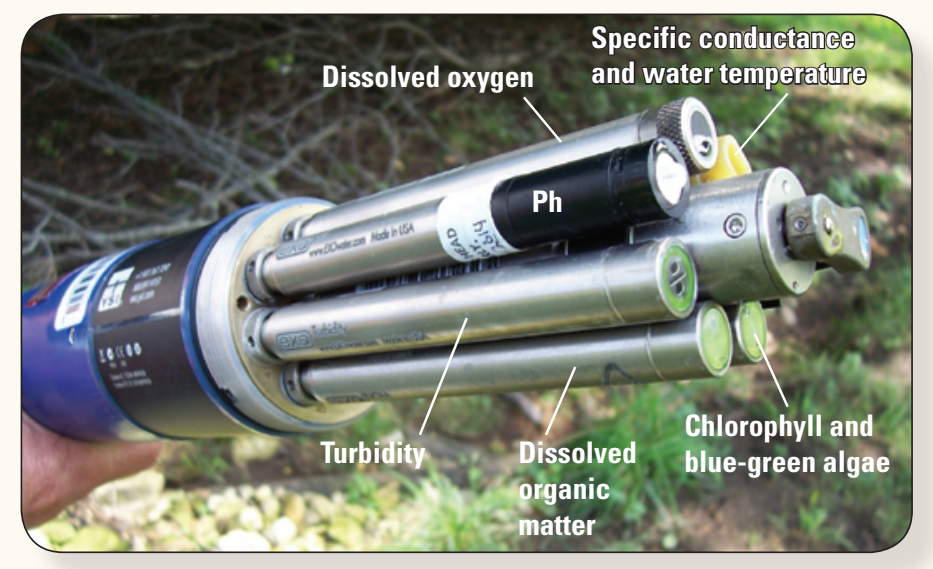

Instream monitor used to collect real-time water quality data. Photograph by Teresa Rasmussen, U.S. Geological Survey.

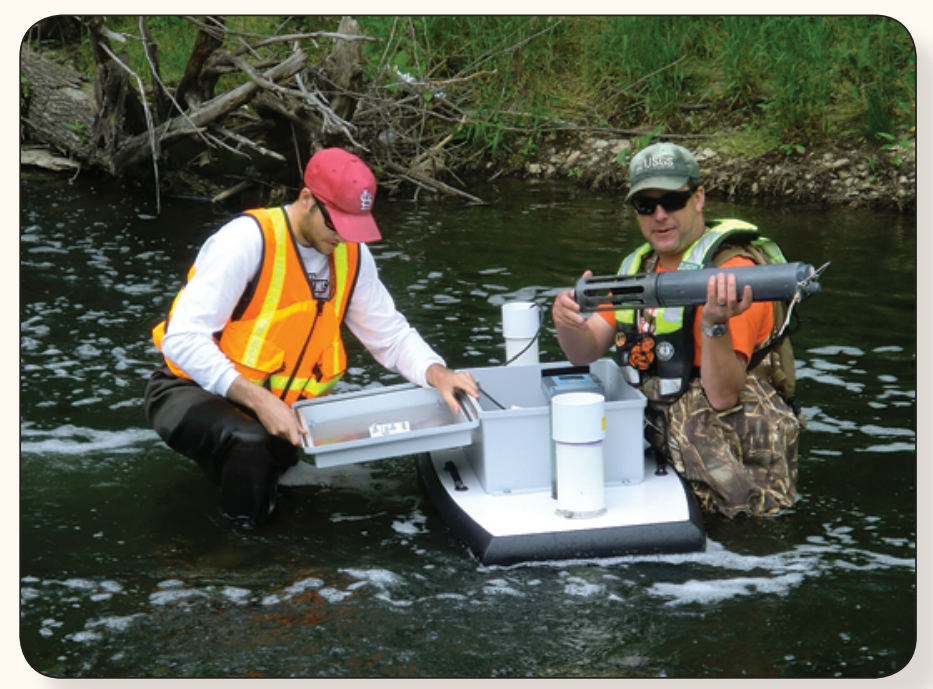

Hydrologists collecting water-quality data to evaluate streams in Johnson County, Kansas. Photograph by Chelsea Paxon, U.S. Geological Survey.

- Monitor sediment loads into and out of reservoirs that are used for water supply, flood control, and recreation, and compute sediment trapping efficiency of the reservoirs;

- Adjust management strategies when high concentrations of water-quality constituents may affect the quality of a water supply; and

- Help preserve the recreational benefits of Kansas waters.

For more real-time water-quality information for Kansas, visit the USGS Web sites at

http://waterwatch.usgs.gov/wqwatch/ and http://nrtwq. usgs.gov/

\section{Benefits to Kansas and the People}

The water resources of Kansas are crucial to our State and represent an important resource that meets countless needs of many people every day. Accurate, timely scientific information is needed to assess, manage, and use the State's water to its greatest benefit.

Publishing support provided by:

Rolla Publishing Service Center

For additional information concerning this publication, contact: Director, USGS Kansas Water Science Center 4821 Quail Crest Place

Lawrence, KS 66049

(785) 842-9909

Or visit the Kansas Water Science Center Web site at: http://ks.water.usgs.gov 